\title{
Aplikasi Taman Bacaan Masyarakat Berbasis Web pada Lembaga Bimbingan Belajar Teknos Kabupaten Sidoarjo
}

\author{
Purnomo $^{1}$, Rudy Setiawan ${ }^{2}$, Yuswanto ${ }^{3}$ \\ ${ }^{1}$ Teknik Industri Universitas Ma Chung Jl. Villa Puncak Tidar N 01 Malang \\ ${ }^{2}$ Sistem Informasi Universias Ma Chng Jl. Villa Puncak Tidar N 01 Malang \\ ${ }^{3}$ Akuntansi Universitas Ma Chung Jl. Villa Puncak Tidar N 01 Malang \\ Correspondence: pur.nomo@machung.ac.id \\ Received: 30 Juni 2021 - Revised: 01 Agustus 2021 - Accepted: 16 Agustus 2021
}

\begin{abstract}
Abstrak. Seiring dengan perkembangan dunia ilmu pengetahuan dan teknologi (IPTEK) yang semakin pesat khususnya pada komputerisasi dan internet maka perkembangan teknologi informasi dengan menggunakan alat bantu komputer dan internet meningkat secara signifikan dalam segala bidang. Taman bacaan masyarakat Lembaga Bimbingan Belajar Teknos dan Kampoeng Sinaoe Kabupaten Sidoarjo merupakan salah satu lembaga bimbingan belajar yang mempunyai perpustakaan dengan berbagai jenis buku yang dapat menunjang dunia pendidikan. Selain kegiatan peminjaman buku yang dilakukan perpustakaan kegiatan lain yakni berupa pengolahan data buku dan penyebaran informasi mengenai perpustakaan Lembaga Bimbingan Belajar Teknos dan Kampoeng Sinaoe Kabupaten Sidoarjo tersebut masih bersifat konvensional. Sehingga dalam memberikan informasi kepada para pengguna perpustakaan masih sangat sulit. Hasil program kemitraanmasyarakat ini adalah Website Perpustakaan Lembaga Bimbingan Belajar Teknos dan Kampoeng Sinaoe Kabupaten Sidoarjo ini memiliki keuntungan sebagai berikut: Dapat diakses menggunakan HP dari mana saja kapan saja melalui jaringan internet, Sebagai media penyampaian informasi yang lebih efisien, Memiliki level akses yang bertingkat sesuai dengan penggunanya (admin dan user).
\end{abstract}

Kata kunci: Aplikasi, Web, bimbel,Teknos, Kampoeng Sinaoe

Citation Format: Purnomo, Setiawan, R., \& Yuswanto. (2021). Aplikasi Taman Bacaan Masyarakat Berbasis Web pada Lembaga Bimbingan Belajar Teknos Kabupaten Sidoarjo. Prosiding Seminar Nasional Abdimas Ma Chung (SENAM), 200-209. 


\section{PENDAHULUAN}

Dalam era globalisasi ini, sudah banyak perpustakaan-perpustakaan di Indonesia yang telah berkembang dengan baik, khususnya perpustakaan-perpustakaan perguruan tinggi dan perpustakaan- perpustakan yang dulunya termasuk dalam sekolah berstandar nasional.

Kondisi perpustakaan di perkotaan dan perpustakaan perguruan tinggi sangat berbeda dengan kondisi di Taman Bacaan Masyarakat (TBM) yang saat ini juga tumbuh subur di berbagai daerah. Meskipun keberadaan Taman Baca di kota Sidoarjo saat ini berkembang pesat, tetapi dalam pengelolaannnya taman baca ini belum tertata dengan baik. Taman baca tersebut hanya memajang koleksi yang mereka punya di rak-rak kayu atau bahan lain yang ada. Permasalahan ini ditambah dengan bentuk pengelolaan terhadap sarana dan prasarananya yang belum tertata dengan rapi. Taman baca yang ideal yaitu taman baca yang memiliki standar koleksi perpustakaan, standar sarana dan prasarana, standar pelayanan, standar tenaga, standar penyelenggaraan, dan standar pengelolaan. Permasalahan umum yang terjadi adalah manajemen taman baca rata-rata belum memenuhi standar di atas, dikarenakan beberapa keterbatasan yang dimiliki. Keterbatasan itu dipengarui oleh kemampuan pengelola dan kondisi sosial ekonomi dan politik masyarakat setempat yang belum mendukungnya.

Lembaga bimbingan belajar (bimbel) merupakan sebuah lembaga non formal yang melayani pendidikan siswa yang dilakukan di luar jam sekolah. Saat ini, bimbel telah menjadi suatu kebutuhan pagi para siswa, khususnya siswa yang akan melanjutkan studinya ke perguruan tinggi. Lembaga Bimbingan Belajar Teknos dan Kampoeng Sinaoe Kabupaten Sidoarjo adalah salah satu bimbingan belajar, yang mempunyai perpustakaan yang bertujuan menyediakan buku pelajaran SD, SMP dan SMA, kamus, jurnal, dan sebagainya yang sesuai dengan kebutuhan siswa Sekolah tersebut. Dengan demikian dapat meningkatkan prestasi dan wawasan para siswa. Sehingga proses belajar mengajar di Lembaga bimbingan belajarpun akan semakin baik. Namun sejauh ini terdapat kendala yang dihadapi perpustakaan Lembaga Bimbingan Belajar (LBB) Teknos dan Kampoeng Sinaoe Kabupaten Sidoarjo dalam hal pelayanan informasi. Hal ini dapat dilihat dalam penyediaan informasi data buku, data sastra, data artikel, data berita, dan data anggota. Proses ini masih lambat dan biasanya kurang menghasilkan informasi yang sesuai dengan kebutuhan pemakai atau masih sering terjadi kesalahan. Peran taman bacaan masyarakat (TBM) dalam menumbuhkan minat membaca dan 
menulis pada masyarakat adalah suatu upaya mendayagunakan sumberdaya insani yang terlibat dalam mendukung aktivitas pengelolaan kegiatan TBM sehingga mampu mendorong minat masyarakat untuk gemar membaca dan menulis. Pengelolaan taman baca di LBB Teknos dan Kampoeng Sinaou diperlukan karena dalam rangka menunjang proses belajar masyarakat dan menumbuhkan minat baca bagi masyarakat sekitar sehingga dapat meningkatkan kualitas masyarakat.

Salah satu intrumen untuk membangkitkan budaya gemar belajar melalui masyarakat gemar membaca adalah dengan tersedianya taman bacaan masyarakat (TBM). TBM adalah suatu lembaga/tempat yang menyediakan bahan bacaan yang dibutuhkan oleh masyarakat, dan sebagai tempat penyelenggaraan program pembinaan kemampuan membaca dan belajar masyarakat, (Kusnadi, 2005). Diselenggarakannya taman bacaan selain untuk mewujudkan masyarakat gemar membaca, juga dimaksudkan untuk mendukung pendidikan keaksaraan. (Depdiknas, 2005).

\section{MASALAH}

Secara umum permaslahan kegiatan pengabdian ini belum menemukan model taman bacaan masyarakat (TBM) yang secara konseptual memenuhi standar akademik dan secara implementatif dapat membantu penguatan program minat baca pada wilayah kabupaten Sidoarjo. Untuk memelihara keberlangsungan penyelenggaraan TBM diperlukan berbagai alternatif dalam pengelolaannya, untuk mencapai tujuan tersebut Taman Baca LBB Teknos Genius Kartini Sidoarjo dan Kampoeng Sinaoe melakukan manajemen pengelolaan meliputi pengelolaan taman baca, kegiatan dan program peminjaman buku dengan perangkat lunak
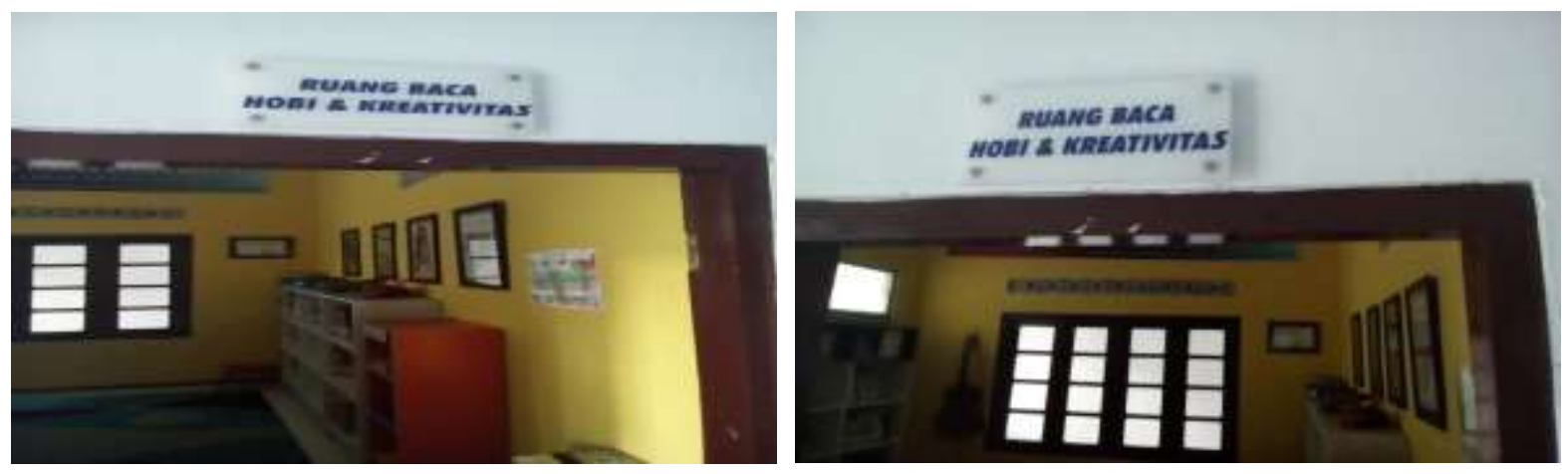

Gambar 1. Ruang perpustakaan LBB Teknos 


\section{METODE KEGIATAN}

Beberapa tahapan kegiatan yang dilakukan selama kegiatan abdmas program kemitraan Masyarakat (PKM), sebagai berikut :

a. Pendekatan Kegiatan

Pendekatan dalam kegiatan ini adalah pengembangan sistem dimana pengamatan yang dilakukan mencakup segala hal yang berhubungan dengan kegiatan program kemitraan Masyarakat.

b. Analisis Aplikasi

Melakukan analisis aplikasi yang sedang berjalan saat itu dengan maksud untuk mengidentifikasi dan mengevaluasi permasalahan-permasalahan, kesempatan, hambatan yang terjadi dan kebutuhan kebutuhan yang diharapkan.

c. Waktu dan Tempat Kegiatan.

Kegiatan PKM dilaksanakan di Perpustakaan Lembaga Bimbingan Belajar Teknos dan Taman Bacaan Kampoeng Sinaoe Desa Siwalan Panji Kabupaten Sidoarjo.

d. Teknik Pengumplan Data

Tahap ini adalah tahap pembelajaran konsep tentang sistem pembuat keputusan dan metode pembelajaran. Dalam pemahaman serta penjelasan konsep ini didapat dari bukubuku referensi, jurnal penelitian ataupun artikel yang didapat dari internet.

e. Pembuatan Aplikasi

Tahap ini dilakukan jika perancangan desain aplikasi telah selesai dibuat dan memberi nama TBM Kartini

f. Uji Aplikasi

Tahapan dimana aplikasi yang telah dirancang akan diuji keakuratannya apakah sudah bebas dari kesalahan-kesalahan sesuai dengan metode pengujian.

g. Implementasi

Implementasi aplikasi adalah tahapan pendampingan ke TBM LBB Teknos dan TBM Kampoeng Sinaoe antara lain aplikasi pencarian buku, aplikasi pengguna, dan membuat user name serta password. 


\section{HASIL DAN PEMBAHASAN}

Hasil aplikasi adalah tahapan pendampingan ke TBM LBB Teknos dan TBM Kampoeng Sinaoe antara lain aplikasi pencarian buku, aplikasi pengguna, dan membuat user name serta password.

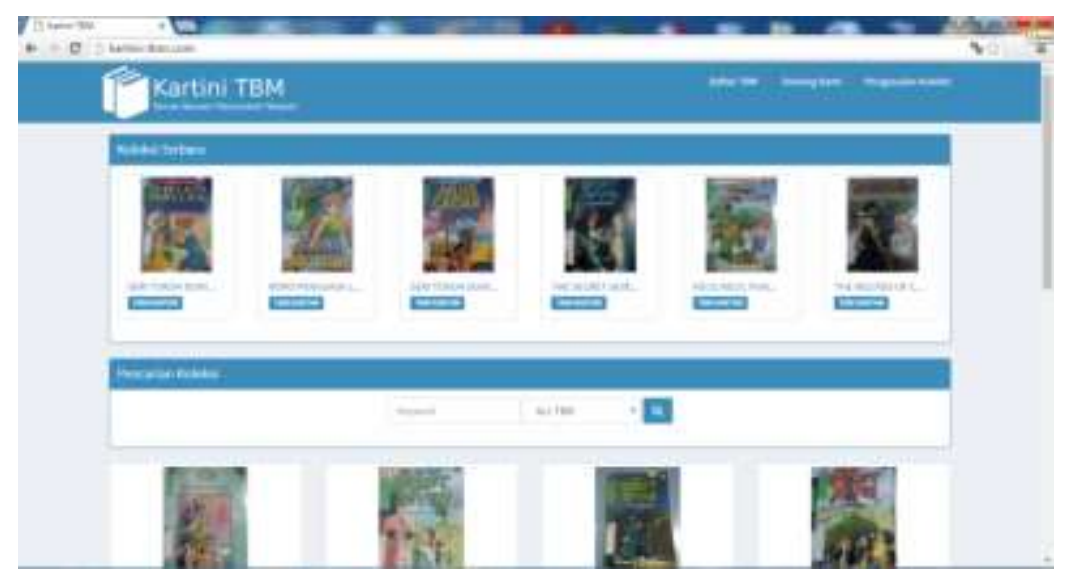

Gambar 2. Tampilan Awal.

Gambar 2 adalah tampilan awal pembukaan katalog Taman Bacaan Masyarakat di Lembaga Bimbingan Belajar Teknos Kartini dan Kampoeng Sinaoe Kabupaten Sidoarjo.

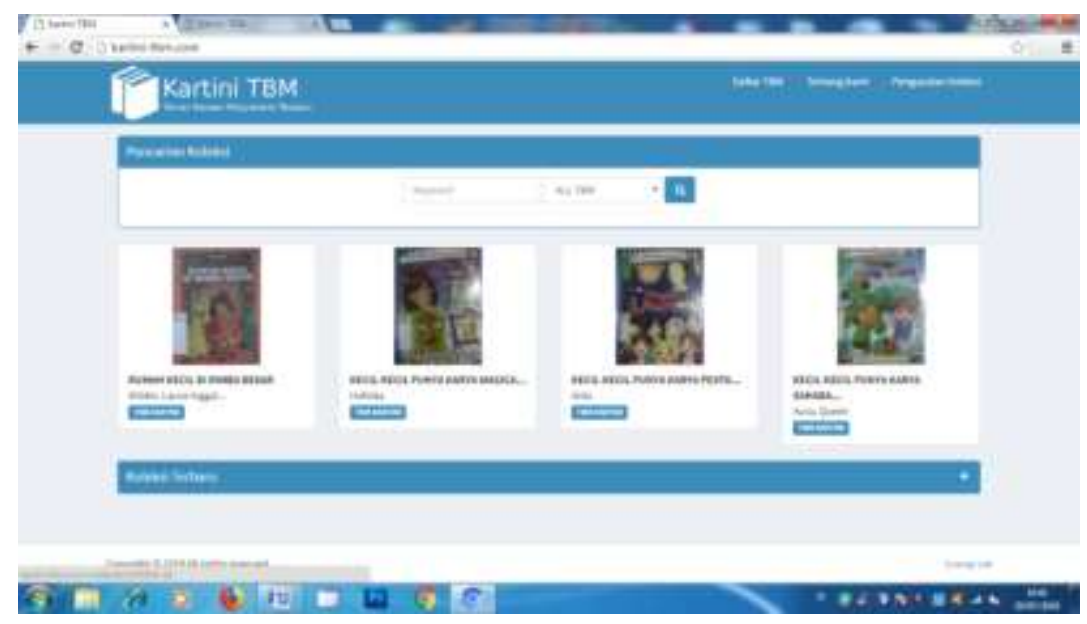

Gambar 3. Pencarian Koleksi

Pada gambar 3 untuk mencari koleksi buku - buku yang ada pada LBB Teknos dan Kampoeng Sinaou Kabupaten Sidoarjo. 


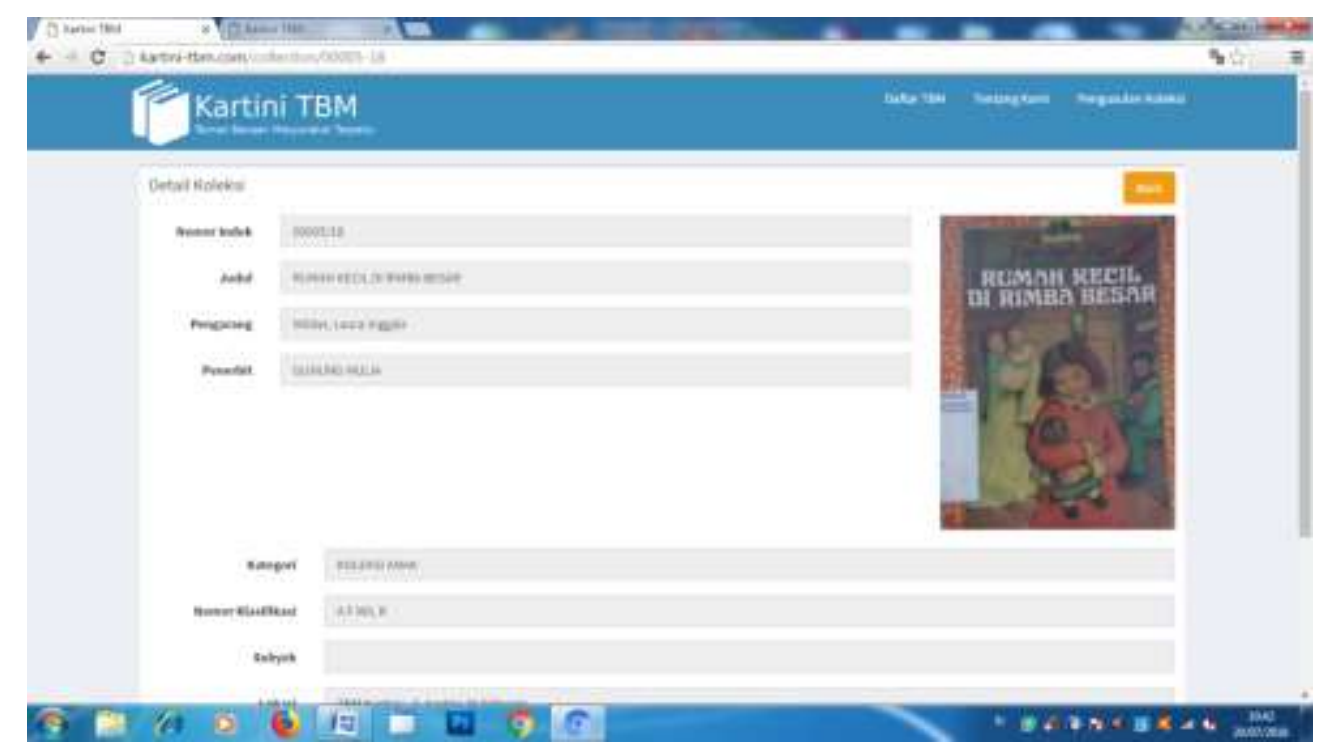

Gambar 4. Koleksi Terpilih.

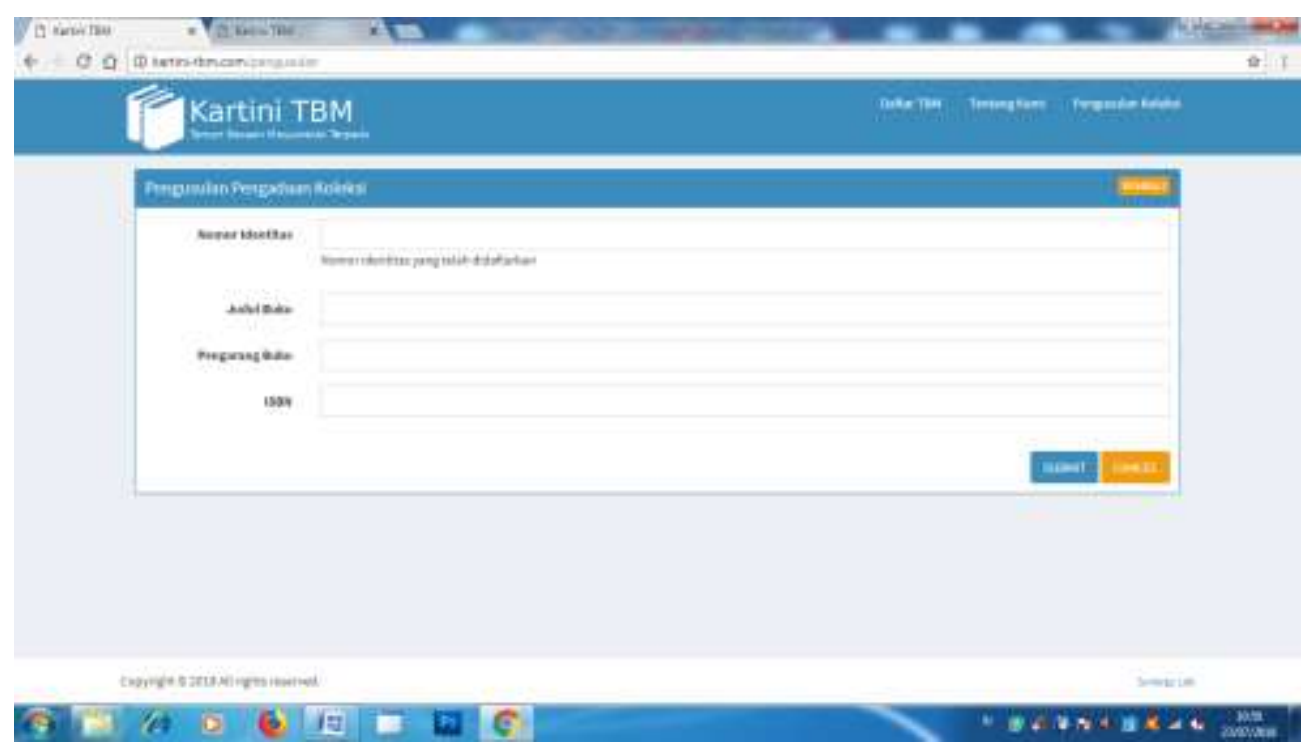

Gambar 5. Tampilan Pengguna

Pada gambar 5 adalah tampilan pengguna (pemustaka) atau pengusul (mengusulkan buku) pengusul buku yang belum ada di TBM (Taman Bacaan Masyarakat) Kampoeng Sinaoe Sidoarjo. 

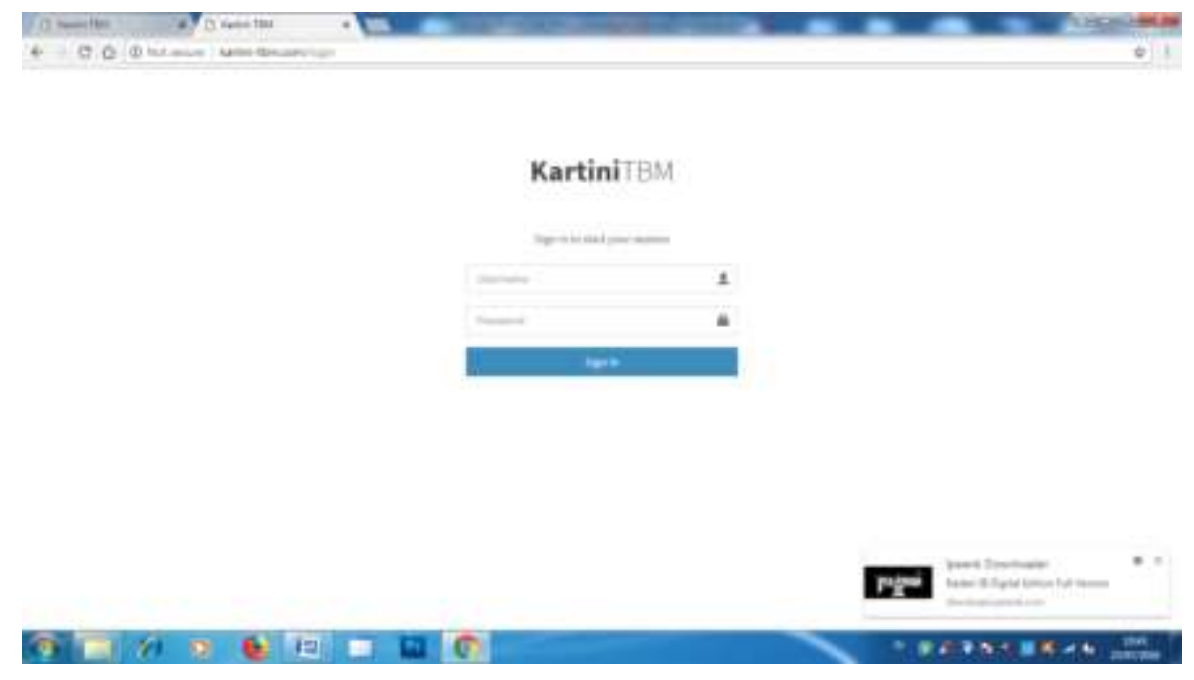

Gambar 6. Kartini TBM Manage

Gambar 6 adalah menu untuk masuk ke aplikasi Kartini TBM (Taman Bacaan Masyarakat) dan LLB Kampoeng Sinau

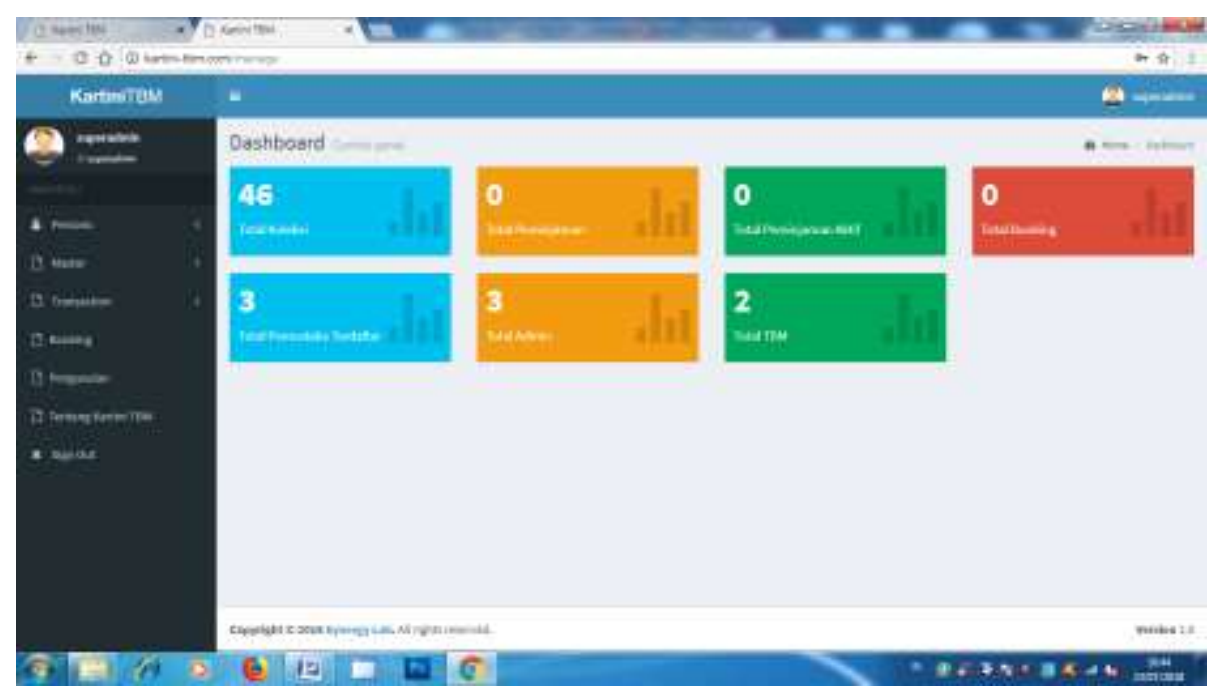

Gambar 7. Dashboard Awal

Gambar 7 adalah dashboard awal untuk mengetahui total buku yang dipinjam dan pengembalian buku. 


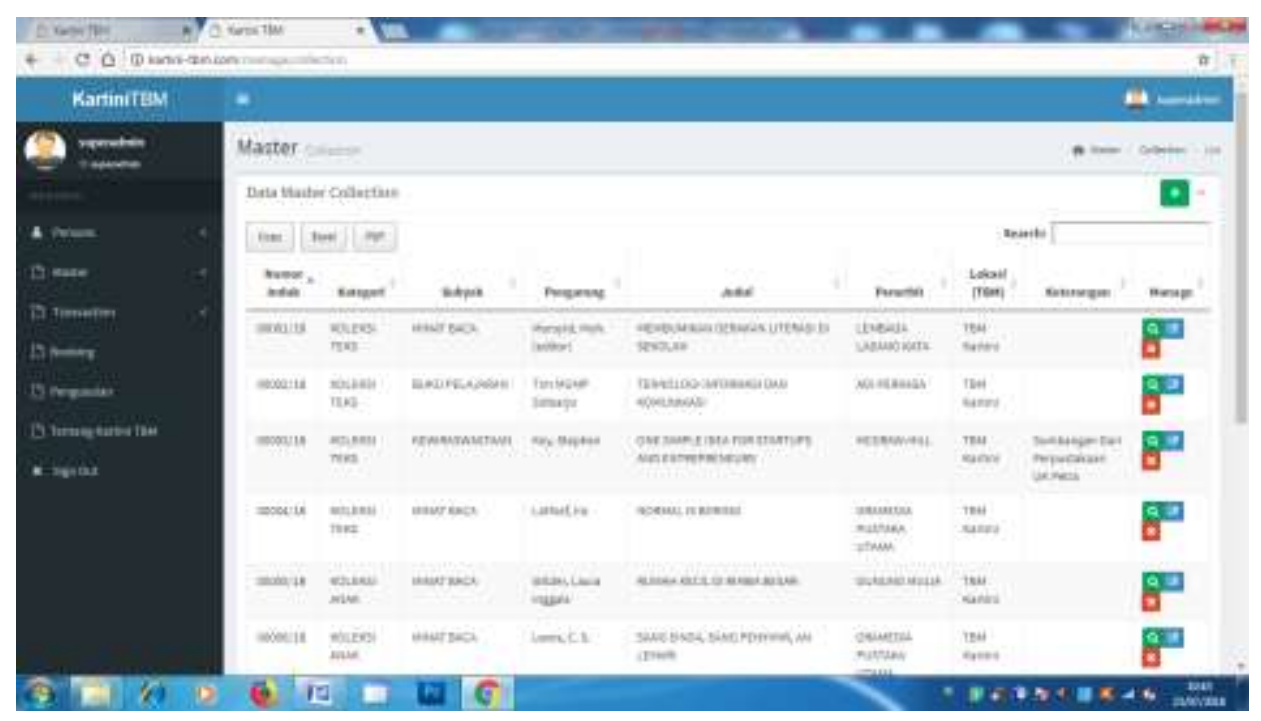

Gambar 8. Data Master Collection

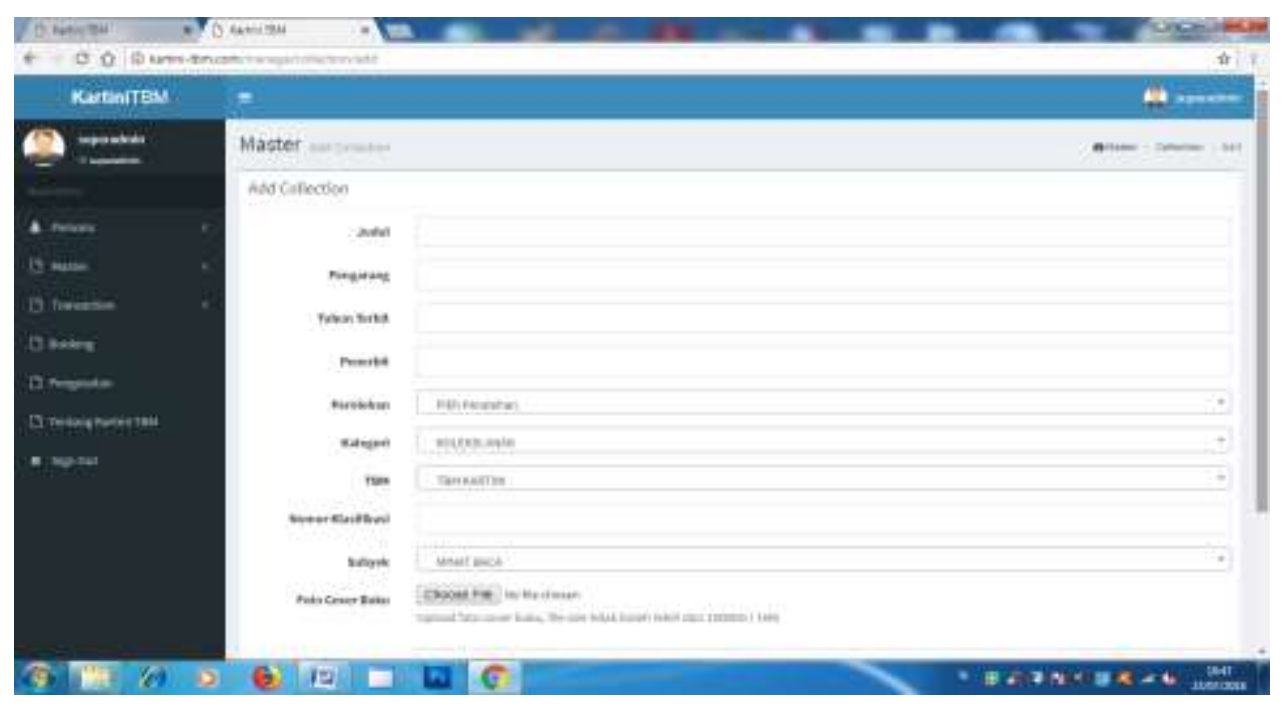

Gambar 9. Penambahan Data Koleksi 


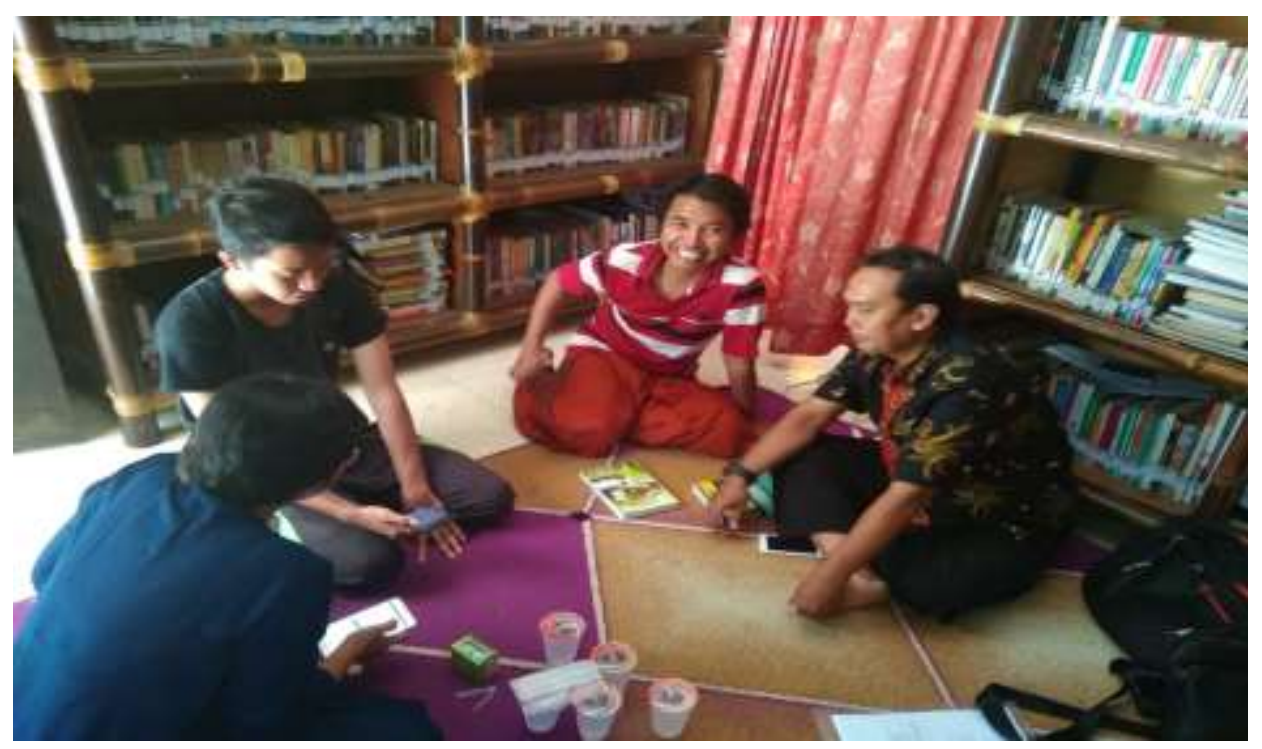

Gambar 10. Implementasi Aplikasi TBM

\section{KESIMPULAN}

Adapun kesimpulannya adalah sebagai berikut :

1. Website Perpustakaan Taman Bacan Masyarakat LBB Teknos dan TBM Kampoeng Sinaoe Kabupaten Sidoarjo ini memiliki keuntungan, sebagai berikut :

a. Dapat diakses dari mana saja kapan saja melalui jaringan internet dan diakses menggunakan HP

b. Sebagai media penyampaian informasi yang lebih efisien.

c. Memiliki level akses yang bertingkat sesuai dengan penggunanya (admin dan user).

2. Dalam teknologi pemrograman aplikasi berbasis web yang telah dikembangkan, juga dapat dijadikan sebagai salah satu pilihan utama dalam pembuatan aplikasi berbasis web karena keunggulannya dan kemudahan dalam pemakaian.

3. Cukup membantu dalam pengembangan website Perpustakaan LBB Teknos dan TBM Kampoeng Sinaoe Kabupaten Sidoarjo. 


\section{UCAPAN TERIMA KASIH}

Peneliti mengucapkan terima kasih kepada Lembaga Bimbingan Belajar Teknos dan Lembaga Bimbingan Belajar Kampoeng Sinaou dan jajarannya yang telah memberikan izin melakukan pengabdian Masyarakat di lingkungan LBB Teknos dan Kampoeng Sinaou. Peneliti juga mengucapkan terima kasih kepada peneliti lain yang telah menjadi sumber referensi dalam penelitian ini

\section{DAFTAR PUSTAKA}

Departemen Pendidikan Nasional. 2008. Naskah Akademik Pengelola Taman Bacaan Masyarakat (TBM). Direktorat Jenderal Peningkatan Mutu.

Departemen Pendidikan Nasional. 2005 Pedoman Pengelolaan Taman Bacaan Masyarakat. Jakarta: Depdiknas.

Departemen Pendidikan Nasional. 2008. Naskah Akademik Pengelola Taman Bacaan Masyarakat (TBM). Direktorat Jenderal Peningkatan Mutu Pendidik dan Tenaga Kependidikan, Direktorat Pendidik dan Tenaga Kependidikan Nonformal, Jakarta

Kusnadi, dkk. 2005 Pendidikan Keaksaraan, Filosofi, Stategi, Implementasi. Depatemen Pendidikan Nasional, Jakarta, hal. 41.

(C) 2021 by authors. Content on this article is licensed under a Creative Commons Attribution 4.0 International license. (http://creativecommons.org/licenses/by/4.0/). 